\title{
Optimization and Mechanisms for Biodecoloration of a Mixture of dyes by Trichosporon akiyoshidainum HP 2023
}

\section{María M. Martorell , María del M. Rosales Soro, Hipólito F. Pajot \& Lucía I. C.} de Figueroa

To cite this article: María M. Martorell , María del M. Rosales Soro, Hipólito F. Pajot \& Lucía I. C. de Figueroa (2017): Optimization and Mechanisms for Biodecoloration of a Mixture of dyes by Trichosporon akiyoshidainum HP 2023, Environmental Technology, DOI: 10.1080/09593330.2017.1375024

To link to this article: http://dx.doi.org/10.1080/09593330.2017.1375024

Accepted author version posted online: 01

Sep 2017.

Submit your article to this journal $\sqsubset$

View related articles $\sqsubset$

View Crossmark data 
Publisher: Taylor \& Francis \& Informa UK Limited, trading as Taylor \& Francis Group

Journal: Environmental Technology

DOI: $10.1080 / 09593330.2017 .1375024$

Optimization and Mechanisms for Biodecoloration of a Mixture of dyes by

Trichosporon akiyoshidainum HP 2023

María M. Martorell ${ }^{1}$, María del M. Rosales Soro $^{2}$, Hipólito F. Pajot ${ }^{2}$, Lucía I. C. de

Figueroa $^{2,3}$

${ }^{1}$ Instituto Antártico Argentino

${ }^{2}$ PROIMI - CONICET (Planta Piloto de Procesos Industriales Microbiológicos)

${ }^{3}$ Cátedra de Microbiología Superior, Facultad de Bioquímica, Química y Farmacia,

Universidad Nacional de Tucumán, Tucumán, Argentina

Corresponding author: M.M. Martorell

Instituto Antártico Argentino

Junín 956, C1113AAD, Ciudad Autónoma de Buenos Aires, Argentina.

Tel: +5401152874673

Fax:+54381 4344887

E-mail addresses: marmartorellsaez@gmail.com, mariamartha86@hotmail.com,

\section{ABSTRACT}

Trichosporon akiyoshidainum HP2023 is a basidiomycetous yeast isolated from Las Yungas rainforest (Tucumán, Argentina) and selected based on its outstanding textile dye decolorizing ability. In this work, the decolorization process was optimized using Reactive Black 5 as dye model. Lactose and urea were chosen as carbon and 
nitrogen sources through a one-at-time approach. Afterwards, factorial designs were employed for medium optimization; leading to the formulation of a simpler optimized medium which contains in $\mathrm{g} \mathrm{L}^{-1}$ : lactose 10 , yeast extract 1 , urea $0.5, \mathrm{KH}_{2} \mathrm{PO}_{4} 1$ and $\mathrm{MgSO}_{4} 1$. Temperature and agitation conditions were also optimized. The optimized medium and incubation conditions for dye removal were extrapolated to other dyes individually and a mixture of them. Dye removal process happened through both biosorption and biodegradation mechanisms, depending primarily on dye structure. A positive relation between initial inoculum and dye removal rate and a negative relation between initial dye concentration and final dye removal percentages were found. Under optimized conditions Trichosporon akiyoshidainum HP2023 was able to completely remove a mixture of dyes up to a concentration of $300 \mathrm{mg} \mathrm{L}^{-1}$, a concentration much higher than those expected in real effluents.

Keywords: Biodecolorization, biosorption, Dyes, Yeasts, Media Optimization. 


\section{Introduction}

In the past decades, pollution of water bodies contaminated with dyestuffs has been increasingly serious. It is estimated that nearly $300,000 \mathrm{t}$ of textile dyes are discharged into the nature environment every year, among which, azo dyes characterized by one or more azo groups $(\mathrm{N}=\mathrm{N})$, account for the majority. Such azo dyes-containing effluents are aesthetically unpleasant, but the major problem is that most azo dyes and their metabolic intermediates are toxic, carcinogenic, and mutagenic to most living organisms [1].

Various technologies such as physical, chemical, and biological methods have been developed to treat this kind of industrial effluents. However, conventional treatments are impractical to industrial application since they proved to be expensive and prone to produce large amounts of secondary pollution. By contrast, microbial removal processes have become the dominant technology with the merits of being ecofriendly and cost competitive [2].

The effectiveness of microbial decolorization depends on the adaptability and activity of the selected microorganisms. Consequently, several species have been tested for the decolorization and degradation of different dyes in recent years. Most existing reports about microbial decolorization and degradation of azo dyes were focused on fungi, bacteria, actinobacteria and algae. Despite presenting several advantages for their use in bioremediation processes, including a great capacity for accumulating dyes, fast unicellular growth, the ability to survive harsh environments and faster decolouration

rates than most filamentous fungi, yeast has attracted little attention until the last two decades $[1,4]$.

Known yeast species with dye removal abilities are mainly ascomycetous, including some belonging to Candida, Saccharomyces, Kluyveromyces and 
Debaryomyces genera. Among basidiomycetous, Trichosporon and Rhodotorula are the most promising genera [4]. According to Pajot et al. [5] the apparent lack of basidiomycetous yeast with biodecoloration properties is striking, considering the production of ligninolytic enzymes and the widely spread unicellular mode of growth between basidiomycetes.

It is currently accepted that dye removal by yeast occurs via two main processes, biosorption and biodegradation, either individually or together depending on environmental conditions. Biosorption involves no energy consumption and may occur in both, dead and living cells. The dye-cell binding is primarily by union of the dye to the nitrogen groups in peptidoglycans or proteins associated with cell wall. It may also be through binding to active groups in cell surface, such as acidic polysaccharides, lipids, amino acids, and other cellular components. Dye biosorption is a well characterized phenomenon, depending mainly on environmental factors such as $\mathrm{pH}$, initial dye concentration and biomass dosage and time [6]. On the other hand, biodegradation process changes the molecular structure of a compound, where the complete mineralization into simpler substances such as $\mathrm{CO}_{2}, \mathrm{H}_{2} \mathrm{O}$ or $\mathrm{CH}_{4}$, is the most desired result. When the compound is not completely mineralized, the process is called biotransformation. Yeast biotransformation or biodegradation of azo dyes by enzymatic mechanisms occurs either by reduction or oxidation mechanisms. Generally, reductive reactions lead to cleavage of the azo bond with the consequent formation of aromatic amines, further metabolized by yeast. An oxidative cleavage of the azo bond is performed by the action of ligninolytic enzymes such as laccases, manganese peroxidases, lignin peroxidases, etc. [7].

Several physicochemical operational parameters have a direct influence on microorganism-mediated decolorization processes; such as agitation, dissolved oxygen, 
temperature, $\mathrm{pH}$, concentration and structure of the dye or dyes tested, additional carbon and nitrogen sources, etc. To increase efficiency, speed, and practicality of process implementation, determining the effect of each factor in the dye removal process is essential [8].

The present work is focused on the optimization of media composition in three different factorial designs steps, in comparing with most reported works were only one step is done, and operational condition for biodecoloration of several dyes by Trichosporon akiyoshidainum HP 2023 a fast dye-decolourizing yeast previously isolated from the Las Yungas rainforest (Tucumán, Argentina) in submerged fermentation [9]. Effects of different factors on the aerobic dye removal by growing cells and mechanism involved in biodecolorization process were also investigated.

\section{Materials and Methods}

Yeast

Yeast T. akiyoshidainum HP-2023, isolated from 'Las Yungas' and selected by its decolorization potential [5], is currently maintained in the American Type Culture Collection as accession number ATCC MYA-4129 and in the Central Bureau Voor Schimmelcultures under accession number CBS 10550. For routine work at the laboratory scale, yeast cultures are maintained on NDM agar slants at $4^{\circ} \mathrm{C}$ and subcultured at 15 days intervals.

\section{Culture Media and Dyestuff}

Normal decolorization medium (NDM; in $\mathrm{g} \mathrm{L}^{-1}$ : glucose, 20; yeast extract, 2,5; $\left(\mathrm{NH}_{4}\right)_{2} \mathrm{SO}_{4}, 5 ; \mathrm{KH}_{2} \mathrm{PO}_{4}, 5$; and $\mathrm{MgSO}_{4} \cdot 7 \mathrm{H}_{2} \mathrm{O}, 0,5$ and $\mathrm{CaCl}_{2}$ 0.13) [10] was used as the basic medium for the optimization design. 
The azo dyes Reactive Black 5, Reactive Red 121, Reactive Blue 221 and Reactive Yellow 84, (Figure 1, near here) were kindly provided by Vilmax S.A. Stock solutions were prepared by dissolving powdered dyestuff, without prior purification, in distilled water up to a concentration of $2 \mathrm{~g} \mathrm{~L}^{-1}$ and filter-sterilized (Millipore filter, 0.22mm; Millipore Corp., Bedford, USA).

\section{Growth and Decolorization in Liquid Cultures}

Decolorization kinetics were evaluated in $500 \mathrm{~mL}$-Erlenmeyer flasks containing $100 \mathrm{~mL}$ of NDM medium or the medium under evaluation, plus the dye assayed at a final concentration of $200 \mathrm{mg} \mathrm{L}^{-1}$, unless otherwise stated. 10-ml yeast suspension $\left(\mathrm{OD}_{550}=0.8\right)$, prepared from a $16 \mathrm{~h}$ old NDM broth culture were used to inoculate the flasks. Incubations, unless otherwise specified, were carried out at $25^{\circ} \mathrm{C}$ and $250 \mathrm{rpm}$ for $24 \mathrm{~h}$. Biotic and abiotic controls were performed in all the experiments. Samples were aseptically collected at different time intervals and centrifuged for $10 \mathrm{~min}$ at $6500 \mathrm{~g}$. Pellets were washed twice with sterile water and dried at $80^{\circ} \mathrm{C}$ to constant weight for biomass dry weight and biomass color determination. Supernatants were kept for estimating dye removal and $\mathrm{pH}$.

\section{Dye Monitoring}

Dye decolorization was determined by using culture supernatants obtained as above described. Percent color removal (R) of each dye was calculated at its $\lambda_{\text {opt }}$ (which are: Reactive Black 5, 495 nm; Reactive Red 121, 540 nm; Reactive Blue 221, $610 \mathrm{~nm}$ and Reactive Yellow 84, $410 \mathrm{~nm}$ ) as percent decolorization, as follows:

$$
R(\%)=\frac{A_{0}-A_{t}}{A_{0}} \times 100
$$


Where $A_{0}$ and $A_{t}$ were the absorbance of dye-amended medium at the start point $(0)$ and at a cultivation time $(\mathrm{t})$, respectively.

Additionally, culture supernatants were subjected to spectral scanning between 300 and $700 \mathrm{~nm}$, to analyze dye disappearance in the mixture of all dyes. For each wavelength, a percentage decrease was calculated, comparing the initial absorbance (culture start) from the final absorbance (sample taken). The overall percent removal of the dye mixture was evaluated as the average percentage decrease previously obtained.

\section{Effect of Carbon and Nitrogen Sources on Decolorization}

Reactive Black 5 was used as the model dye. Glucose, lactose, sucrose, and glycerol, were assayed at equivalent carbon concentrations, as carbon and energy sources. Also, three nitrogen sources were evaluated, $\left(\mathrm{NH}_{4}\right)_{2} \mathrm{SO}_{4}$, urea and $\mathrm{NH}_{4} \mathrm{NO}_{3}$. Equivalent nitrogen concentrations were also employed in every case. Following a combinatorial scheme, the resulting 12 media were evaluated. Biomass and dye removal were measured as above described. Specific decolorization rate $\left(\mathrm{v}, \mathrm{mg}\right.$ dye removed $\mathrm{g}^{-1}$ biomass $\mathrm{h}^{-1}$ ) was also calculated for each medium.

\section{Effect of Trace Elements on Decolorization}

The effect of $\mathrm{MgSO}_{4} \cdot 7 \mathrm{H}_{2} \mathrm{O}$ and $\mathrm{CaCl}_{2}$ over dye removal was assayed by preparing three different media, with and without both salts and one without $\mathrm{CaCl}_{2}$.

Biomass and dye removal were measured as above described.

\section{Experimental Design and Statistical Analysis}

Two five-factor fractional factorial designs were employed. Glucose, yeast extract, urea, $\mathrm{KH}_{2} \mathrm{PO}_{4}$ and $\mathrm{MgSO}_{4} \cdot 7 \mathrm{H}_{2} \mathrm{O}$, were the variables under study. Two extra 
replicates were included as center points, and thus a total of 34 and 18 experiments were employed in these two designs (Tables 1 and 2, near here). After that, a two-factor full factorial design was employed where the presence or absence of urea and $\mathrm{KH}_{2} \mathrm{PO}_{4}$ were the variables under study (Table 3, near here). The central point replicates in each design were chosen to verify any change in the estimation procedure, as a measure of precision property. These three factorial designs were done to minimize the amount and concentration of the culture media components needed for total dye decolorization.

Samples were taken at 12 and $24 \mathrm{~h}$ of incubation. Biomass, $\mathrm{pH}$ and dye removal were measured as above described. Specific decolorization rate was also calculated for each sample.

\section{Effect of Incubation Conditions on Decolorization}

Once optimized the composition of the culture medium, optimal temperature and agitation conditions were also determined on a one-at-a-time approach. To evaluate temperature influence, flasks were incubated at 20,25 and $30^{\circ} \mathrm{C}$. After that, agitation effect was assayed at 200,250 and $300 \mathrm{rpm}$ under optimal temperature. Samples were taken at 12 and $24 \mathrm{~h}$ of incubation. Biomass, $\mathrm{pH}$ and dye removal were measured as above described.

\section{Evaluation of Optimized Medium on other Dyes Decolorization}

To evaluate whether the optimal conditions could be extrapolated to other dyes, decolorization in NDM and $\mathrm{NDM}_{\mathrm{opt}}$ media were carried out for Reactive Black 5, Reactive Red 121, Reactive Blue 221, and Reactive Yellow 84, and the mixture of these four dyes. In all cases, initial dye concentration was $200 \mathrm{mg} \mathrm{L}^{-1}$, to simulate the absorbance spectrum observed in the real effluent described by O'Neill et al. [11]. 
Samples were taken at 12 and $24 \mathrm{~h}$ of incubation. Biomass, $\mathrm{pH}$, dye removal, biomass color and specific decolorization rate were measured as above described.

\section{Effect of initial Inoculum on Dye Mixture Removal}

The effect of initial inoculums size in the decoloration process was also measured by using $\mathrm{NDM}_{\mathrm{opt}}$ with the dye mixture at an initial concentration of $200 \mathrm{mg} \mathrm{L}$

${ }^{1}$. Different volumes of the cell suspension obtained as previously described were used, which allowed it to evaluate six initial biomass concentrations ranging from 0.08 to 2.8 $\mathrm{g} \mathrm{L}^{-1}$. Samples at initial time, 6, 9, 12 and $24 \mathrm{~h}$ were taken. Biomass, $\mathrm{pH}$, dye removal and specific decolorization rate were measured as above described.

\section{Evaluation of initial Dye-Mixture Concentration on Decolorization}

In order to determine the effect of different initial concentration of the mixture of dyes on decolorization, eight different concentrations were assayed 100, 200, 300, 400, 500, 600, 700 and $800 \mathrm{mg} \mathrm{\textrm {L } ^ { - 1 }}$. Samples at initial time, 3, 6, 9, 12 and $24 \mathrm{~h}$ were taken. Biomass, $\mathrm{pH}$, specific decolorization rate and dye removal were measured as above described.

\section{Enzymatic Activities}

Laccase (Lacc) experiments were based on the oxidation of 2,2'-azino-bis(3ethylbenzothiazoline-6-sulphonic acid) (ABTS, Sigma-Aldrich) followed by the increase in absorbance at $420 \mathrm{~nm}$ in a reaction mixture containing $1,8 \mathrm{mM}$ ABTS in 100 $\mathrm{mM}$ citrate buffer ( $\mathrm{pH} 3.5)$ [12]. Mn-dependent peroxidase (MnP) experiments were based on the oxidation of MBTH(3-Methyl-2-benzothiazolinone hydrazone hydrochloride hydrate )/DMAB(p-Dimethylaminobenzaldehyde) followed by the 
increase in absorbance at $610 \mathrm{~nm}$ in a reaction mixture containing $0.07 \mathrm{mM} \mathrm{MBTH}, 1$ mM DMAB, $0.3 \mathrm{mM} \mathrm{MnSO} 4.7 \mathrm{H}_{2} \mathrm{O}, 0.05 \mathrm{mM} \mathrm{H}_{2} \mathrm{O}_{2}$ in $100 \mathrm{mM}$ succinate lactate buffer ( $\mathrm{pH}$ 4.5) [13]. Finally, Phenol oxidase (POX) measurements were based on catechol oxidation followed by the increase in absorbance at $420 \mathrm{~nm}$ in a reaction mixture containing $0.9 \mathrm{mM}$ of cathecol and $0.07 \mathrm{mM}$ MBTH in $50 \mathrm{mM}$ phosphate buffer $(\mathrm{pH}$ 7.4) [14].

\section{Statistical Analysis}

All values and data points presented in this work are the means of at least triplicate determinations of independent assays. All the results, including those of the experimental designs were analyzed using MINITAB 17 (PA, USA). Analysis of variance (ANOVA) was used to detect the significant effects e. Tests were considered significantly different at $\mathrm{p}<0.05$.

\section{Results and Discussion}

Effect of Carbon, Nitrogen Sources, and Trace Elements on Decolorization

The behavior of T. akiyoshidainum HP 2023 in different culture media with Reactive Black 5 was studied based on dye removal and biomass production at 12 and 24 h.

T. akiyoshidainum HP 2023 presented the highest values of biomass in glucose amended media, followed, in descending order, by those media with lactose, sucrose, and glycerol as $\mathrm{C}$ sources.

No significant differences were observed between $\mathrm{N}$ sources at $12 \mathrm{~h}(\mathrm{p}=0.951)$. However, urea allowed a significantly higher biomass production at $24 \mathrm{~h}(\mathrm{p}=0.014)$ regardless of the $\mathrm{C}$ source (Figure 2, near here). 
Reactive Black 5 removal reached $90 \%$ at $12 \mathrm{~h}$ and $100 \%$ at $24 \mathrm{~h}$ in glucose or lactose amended media. Those media with sucrose and glycerol produced significantly less biomass. T. akiyoshidainum produced significantly lower decolorization values with sucrose and glycerol as $\mathrm{C}$ and energy sources, reaching 50 to $90 \%$ at $24 \mathrm{~h}$ (p < 0.001) (Figure 2).

By contrast, no significant differences were observed in dye removal with different $\mathrm{N}$ sources, whether at $12(\mathrm{p}=0.845)$ or $24 \mathrm{~h}(\mathrm{p}=0.974)$, indicating that decolorization, unlike yeast growth, was primarily determined by the source of C.

Three selection criteria were employed: extensiveness of dye removal, specific decolorization rate (Complementary Table 1) and economic concerns. Based on these criteria, lactose and urea were chosen as $\mathrm{C}$ and $\mathrm{N}$ sources, respectively, with the aiming for a potential use in bioremediation processes.

Biodecolorization by yeasts is usually regarded as a co-metabolic process [15]. The use of easily assimilable carbon sources during decolorization of dyes was previously reported for other yeasts and filamentous fungi $[16,17]$. Urea has been also studied as an economic nitrogen source for dye decolourization by Ganoderma sp. [18], Pycnoporus sanguineus [19] and C. tropicalis [17] cultures.

The simultaneous elimination of $\mathrm{CaCl}_{2}$ and $\mathrm{MgSO}_{4}$, present in very low concentrations in the original NDM produced a drastic decline in biomass and dye decolorization $(p<0.05)$. Since no significant differences between the complete medium and media without $\mathrm{CaCl}_{2}$ were observed (Fig. 3, near here), we attribute this effect to the lower sulfur concentrations in media where $\left(\mathrm{NH}_{4}\right)_{2} \mathrm{SO}_{4}$ was substituted by urea as nitrogen source. Magnesium deficiency could also be detrimental to growth and decolorization by itself, as $\mathrm{Mg}$ is a known cofactor for many enzymes associated with 
dye decolorization $[20,21]$. Consequently, lactose, urea, yeast extract, $\mathrm{KH}_{2} \mathrm{PO}_{4}$ and $\mathrm{MgSO}_{4}$ were selected as media components for further optimization.

\section{Optimization of Culture Media for Dye Removal by Factorial Design}

\section{First Factorial Design}

Factors, levels, dye removal (\%), biomass $\left(\mathrm{g} \mathrm{L}^{-1}\right)$ and specific decolorization rate $\left(\mathrm{mg} \mathrm{g}^{-1} \mathrm{~h}^{-1}\right)$ at 12 and $24 \mathrm{~h}$ of cultivation and $\mathrm{pH}$ at 12 and $24 \mathrm{~h}$ of culture for the first fractional-factorial design are shown in Table 1.

After $12 \mathrm{~h}$ cultivation, dye removal mean was $91.81 \%$, with $8.53 \%$ standard deviation and a $95 \%$ confidence interval of 88.84-94. The $\mathrm{pH}$ varied between 4.27 and 5.75, with values of biomass comprised between 2.14 and $3.30 \mathrm{~g} \mathrm{~L}^{-1}$, producing specific decolorization rates ranging between 3.68 and $6.95 \mathrm{mg} \mathrm{g}^{-1} \mathrm{~h}^{-1}$.

In contrast, at 24 hours, average dye removal was 97,19\%, standard deviation $6.08 \%$ and $95 \%$ confidence interval of the mean $95.07-99.32 \%$; $\mathrm{pH}$ values vary between 3.89 and 8.50 and biomass ranged between 3.21 and $7.06 \mathrm{~g} \mathrm{~L}^{-1}$, resulting in specific decolorization rates between 0.79 and 2.65.

No correlation could be detected between $\mathrm{pH}$ and dye removal either after 12 or 24 h cultivation $(p=0.522$ and $p=0.243$, respectively). Similarly, no correlation could be found between biomass production and dye decolorization after $12 \mathrm{~h}$ and $24 \mathrm{~h}(\mathrm{p}=0.423$ and $\mathrm{p} 0.228$ respectively). Those results suggest that $\mathrm{pH}$ driven dye sorption to yeast biomass is not the main decolorization mechanism

As at $12 \mathrm{~h}$ complete dye removals $(100 \%)$ were obtained, this time was chosen for further optimizations, thus reducing growing time and costs associated with the process. Complementary Table 1 shows the results of ANOVA analysis, with an $\mathrm{r}^{2}$ of 0.6387. The analysis showed that, under the conditions tested, only the concentration of 
$\mathrm{KH}_{2} \mathrm{PO}_{4}$ and the interaction between the concentrations of yeast extract and $\mathrm{MgSO}_{4}$, had a significant effect on dye removal, evaluated after $12 \mathrm{~h}(\mathrm{p} \leq 0.05)$. Other components in the culture medium could be set to their lowest concentrations.

$\mathrm{KH}_{2} \mathrm{PO}_{4}$ effect on dye decolorization proved to be negative, with average values of $96 \%$ and $87 \%$ at low and high salt concentrations, respectively. The best option to optimize dye removal at $12 \mathrm{~h}$ was to lower the initial concentration of yeast extract from $0.25 \%$ to $0.125 \%$ while augmenting the $\mathrm{MgSO}_{4}$ from $0.05 \%$ to $0.075 \%$.

Thus, the final composition of the medium partially optimized by fractional factorial model was as follows $(\% \mathrm{w} / \mathrm{v})$ lactose 1 , urea $0.0565,0.125$ yeast extract, $\mathrm{KH}_{2} \mathrm{PO}_{4} 0.25$ and $\mathrm{MgSO}_{4} 0.075$.

\section{Second Factorial Design}

Dye removal (\%), biomass $\left(\mathrm{g} \mathrm{L}^{-1}\right)$ and specific decolorization rate $\left(\mathrm{mg} \mathrm{g}^{-1} \mathrm{~h}^{-1}\right)$ at 12 and $24 \mathrm{~h}$ of cultivation and $\mathrm{pH}$ at 12 and $24 \mathrm{~h}$ of culture for the second fractionalfactorial design are shown in Table 2.

At $12 \mathrm{~h}$ average dye removal was $88 \%$ with a $95 \%$ confidence interval of the mean in $84-92 \%$ decolorization, whereas at $24 \mathrm{~h}$ the average was $89 \%$, with a $95 \%$ confidence interyal of the mean between 86 and 94\%. The $\mathrm{pH}$ in all tests increased during cultiyation, possibly by hydrolysis of urea. Thus, at $12 \mathrm{~h}$ the average was 4.41 whereas at $24 \mathrm{~h}$ was 6.16 . The greatest increase in biomass occurred the initial $12 \mathrm{~h}$ of culture. On average, the cultures reached $1.88 \mathrm{~g} \mathrm{~L}^{-1}$ at $12 \mathrm{~h}$ and $2.47 \mathrm{~g} \mathrm{~L}^{-1}$ at $24 \mathrm{~h}$ of culture. This fast growth along with almost complete dye removal at $12 \mathrm{~h}$ produced higher specific decolorization rates values at $12 \mathrm{~h}$ than at $24 \mathrm{~h}\left(8.34 \mathrm{mg} \mathrm{g}^{-1} \mathrm{~h}^{-1}\right.$ and 3.11 $\operatorname{mg~} \mathrm{g}^{-1} \mathrm{~h}^{-1}$, respectively), based on this data, all future experiments were analyzed at 12 h. 
Complementary Table 3 shows the results of ANOVA analysis for data after 12h, $\mathrm{r}^{2}$ was 0.9732 . As shown, the effects of lactose, yeast extract, $\mathrm{KH}_{2} \mathrm{PO}_{4}$, and urea/yeast extract interaction were significant. For lactose and yeast extract an increase in dye removal was observed at higher concentrations, in contrast, dye removal was better at lower $\mathrm{KH}_{2} \mathrm{PO}_{4}$ concentrations. With respect to urea/yeast extract interaction, dye removal was greater with high levels of both compounds (Complementary Table 3 ). Although the effect of $\mathrm{MgSO}_{4}$ was not significant, total color removal were observed only at the highest salt concentrations. Therefore, based on the results obtained by this analysis, the following partially optimized ( $\% \mathrm{w} / \mathrm{v})$ medium was proposed: lactose 1 , urea 0.05 , yeast extract $0.1, \mathrm{KH}_{2} \mathrm{PO}_{4} 0.1$ and $\mathrm{MgSO}_{4} 0.1$.

\section{Full Factorial Design}

One last design was realized, to study whether the presence of $\mathrm{KH}_{2} \mathrm{PO}_{4}$ and urea had a positive effect on growth and dye removal. Results of dye removal (\%), biomass $\left(\mathrm{g} \mathrm{L}^{-1}\right)$ and specific decolorization rate $\left(\mathrm{mg} \mathrm{g}^{-1} \mathrm{~h}^{-1}\right)$ at 12 and $24 \mathrm{~h}$ of cultivation and $\mathrm{pH}$ at the initial time, 12 and $24 \mathrm{~h}$ of culture for the full-factorial design are shown in Table 3.

After $12 \mathrm{~h}$, urea, $\mathrm{KH}_{2} \mathrm{PO}_{4}$ and the two-way interaction between them showed a significant impact on dye decolorization, $\mathrm{pH}$ and biomass production (Complementary Table 7). Higher concentrations produced maximal dye removal (90-95\%) maximal biomass production (3.64-3.44 $\left.\mathrm{g} \mathrm{L}^{-1}\right)$ and minimal $\mathrm{pH}$ (4.32 to 4.21$)$.

Since both factors were necessary to obtain higher levels of decolorization, the final optimized medium $\left(\mathrm{NDM}_{\mathrm{opt}}\right)$ had the following composition $(\% \mathrm{w} / \mathrm{v})$ : lactose 1 , urea 0.05 , yeast extract $0.1, \mathrm{KH}_{2} \mathrm{PO}_{4} 0.125$ and $\mathrm{MgSO}_{4} 0.1$. 
Media optimization allowed to exclude the unnecessary $\mathrm{CaCl}_{2}$, and to reduce the concentration of most components in original medium, lactose in $50 \%$, urea in $70 \%$, $\mathrm{KH}_{2} \mathrm{PO}_{4}$ in $80 \%$, only $\mathrm{MgSO}_{4}$ concentration needed an increase of $50 \%$. Media optimization for biodecolorization has been widely evaluated for bacteria and filamentous fungi mediated processes. However, most works deal with non-textile dyes (Congo Red or Indigo), initial dye concentrations are usually lower that the ones herein assayed (50-150 $\left.\mathrm{mg} \mathrm{L}^{-1}\right)$ and cultivation times usually exceed 5 days in multiple works reported [22-26].

Effects of Incubation Conditions on Dye Removal

Temperature effect on dye removal and biomass production was evaluated at $250 \mathrm{rpm}$ after 12 and $24 \mathrm{~h}$ (Table 4, near here).

No significant biomass differences where observed between cultures incubated at 20 and $25^{\circ} \mathrm{C}\left(\mathrm{p}=0.159\right.$ and 0.813 , for 12 or $24 \mathrm{~h}$, respectively). However, at $30^{\circ} \mathrm{C}$ biomass production decreased about $70 \%$. Dye decolourization is nowadays regarded as a cometabolic process in non-ligninolytic microorganisms including yeasts [27], filamentous fungi [28] and bacteria [29], both in axenic cultures and forming consortia [30]. Thus, decolorization at $30^{\circ} \mathrm{C}$ was severely affected after $24 \mathrm{~h}$ incubation, however, only cultures incubated at $25^{\circ} \mathrm{C}$ produced complete removal. Consequently, the effect of agitation speed was evaluated at $25^{\circ} \mathrm{C}$.

Even when biomass production was slightly affected by agitation speed at $12 \mathrm{~h}$ incubation $(\mathrm{p}=0.055)$, at $24 \mathrm{~h}$ cultures incubated at $250 \mathrm{rpm}$ produced significantly much biomass ( $\mathrm{p}=0.016)$. Thus $25^{\circ} \mathrm{C}$ and $250 \mathrm{rpm}$ where selected as optimal incubation conditions for further assays. 
Culture Media Effect on other Textile Dyes Decolorization

Biodecolorization of Reactive Yellow 84, Reactive Red 121, Reactive Blue 221 and the mixture of these dyes plus Reactive Black 5, in NDM and NDM ${ }_{\text {opt }}$ where assayed in optimal conditions determined above $\left(25^{\circ} \mathrm{C}\right.$ and $\left.250 \mathrm{rpm}\right)$.

The results of dye removal, biomass production, $\mathrm{pH}$, specific decolorization rates $(v)$ and biomass color at 12 and $24 \mathrm{~h}$ are shown in Table 5 (near here). In all cases, a complete color removal between 12 and $24 \mathrm{~h}$ was observed. Specific decolorization rates (v) at 12 and $24 \mathrm{~h}$ were higher in $\mathrm{NDM}_{\mathrm{opt}}$ for each dye and the mixture as lower values of biomass were obtained.

It should be noted that, although the values of color removal in the dye mixture were $90 \%$ at $24 \mathrm{~h}$ for the two media, NDM and $\mathrm{NDM}_{\text {opt, }}$, the naked eye no color was observed. As shown in Figure 4 (near here), the $10 \%$ residual color is mainly due to the contribution of medium components. Azo dyes Reactive Yellow 84 and Reactive Red 121 proved to be more recalcitrant than Reactive Black 5, possibly to the effect of monochlorotriazine groups. Reactive Blue 221, in the other hand, is a copper-complex formazan dye with monochlorotriazine and sulfatoethylsulfone reactive groups. Despite this, the results confirmed that medium and cultivation conditions optimized for Reactive Black 5 decolorization could be applied to other dyes with different chemical structure and even to a mixture of them.

After centrifuging the cultures with Reactive Red 121 or dye mixture, presented a pale pink tone biomass, possibly due to the dye sorption. No color was observed in the biomass of cultures with Reactive Yellow 84, Reactive Black 5 or Reactive Blue 221 possibly implying the complete biodegradation of these dyes. 
Based on these results, it was decided to continue the experimental work with the mixture of the dye, to achieve a closer approximation to a true textile effluent, which does not have a single dye, but a complex and dynamic mixture of several dyes [31].

\section{Effects of Inoculum Size on Dye-Mixture Removal}

The effect of initial biomass concentration of T. akiyoshidainum HP 2023 were evaluated between 0.08 and $2.8 \mathrm{~g} \mathrm{~L}^{-1}$, with an initial dye mixture concentration of 200 $\mathrm{mg} \mathrm{L}^{-1}$ in $\mathrm{NDM}_{\mathrm{opt}}$ at $25^{\circ} \mathrm{C}$ and $250 \mathrm{rpm}$.

The growth kinetics and decoloration for all tested concentrations of inoculum are observed in Figure 5 (near here). No significant differences were observed in biomass after 24 hours $(\mathrm{p}=0.190)$. Given these results it was considered that biomass production was limited by the initial concentration of nutrients in the culture medium and not by the magnitude of the initial inoculum.

Regarding the effect of initial inoculum in color removal kinetic, a clear positive correlation was observed (Figure 5). Thus, with an initial biomass of $0.08 \mathrm{~g} \mathrm{~L}^{-1}$ a color removal of $85 \%$ was achieyed at 24 hours, while with initial biomass of 1.4 and $2.8 \mathrm{~g} \mathrm{~L}^{-}$ ${ }^{1}$ dye removals were $90 \%$ at 9 and $6 \mathrm{~h}$, respectively. Such positive correlation could be expected in cometabolic processes and was described elsewhere $[4,32]$. Therefore, for the following assays an initial biomass concentration of $2.8 \mathrm{~g} \mathrm{~L}^{-1}$ was chosen to analyze the effect of the initial concentration of dye.

\section{Effects of Initial Dye Concentration}

Growth and dye removal kinetics for the dye mixture initial concentrations tested are shown in Figure 6 (near here). Slightly significant biomass differences could be appreciated between cultures with different initial concentrations of the dye mixture 
$(p=0.057)$. It could be concluded that the dye mixture did not inhibit yeast growth in tested concentrations. The tolerance of T. akiyoshidaynum to several dyes was demonstrated in other culture media [5], but is rare between yeasts with decolorizing capacity such as C. tropicalis TL-F1, Scheffersomyces spartinae TLHS-SF1 and Pichia occidentalis G1 [16, 33, 34].

Percentual dye removal, on the other hand, decreased with the increase in initial dye mixture concentration. Up to $300 \mathrm{mg} \mathrm{L}^{-1}$, a maximum dye decolorization of $92 \%$ was obtained; at concentrations between 400 and $600 \mathrm{mg} \mathrm{L}^{-1}$ decolorization reached $83 \%$; with $700 \mathrm{mg} \mathrm{L}^{-1}$, maximum color removal was $60 \%$ and finally with initial concentrations of $800 \mathrm{mg} \mathrm{L}^{-1}$ the removal of color was $35 \%$.

Despite such decrease, and considering no signifieant differences in biomass production, concentrations above $400 \mathrm{mg} \mathrm{L}^{-1}$ seems to produce maximum specific decolorization rates, $1.94,2.01,2.01,1.86$ and $1.79 \mathrm{mg} \mathrm{g}^{-1} \mathrm{~h}^{-1}$ for initial concentrations of $400,500,600,700$ and $800 \mathrm{mg} \mathrm{L}^{-1}$ rates respectively.

\section{Enzymatic Activities}

Laccase and MnP activities were undetectable both, in the original (NDM) and in the optimized $\left(\mathrm{NDM}_{\mathrm{opt}}\right)$ media, regardless the addition of textile dyes. Conversely, phenoloxidase activity significantly increased in dye-amended media after 12 to $24 \mathrm{~h}$ incubation, disregarding media composition (Table 6, near here), indicating that phenoloxidase activity is induced by textile dyes, and that the faster decolourization in $\mathrm{NDM}_{\mathrm{opt}}$ is unconnected to typical ligninolytic activities. Furthermore, since yeast biomass remains unstained in original and in optimized media, cultures $\mathrm{pH}$ remains perineutral, and aromatic-amines accumulation were not detected in previous assays 
$[15,35,36]$, the participation of chelator mediated Fenton reactions could be hypothesized, and clearly deserves further investigation.

\section{Conclusions}

In this work the optimization process for media composition and incubation conditions for Reactive Black 5 dye using basidiomycetous yeast Trichosporon akiyoshidainum HP 2023 was presented.

Decolorization process proved to be co-metabolic and dependent on extra and easily assimilable $\mathrm{C}$ and $\mathrm{N}$ sources. Urea, chosen as the $\mathrm{N}$ source, not only is an inexpensive nitrogen organic source, but also can buffer the media, promoting a biodegradation process, rather than a biosorption one. The final optimized media, simpler that the original one, presented a higher specific decolorization rate, associated with a lower biomass production. The optimization process was extrapolated to other dyes, and to a mixture of them.

Dye removal process could be associated with both adsorption and biodegradation mechanisms, depending on the dye structure primarily. A positive relation between initial inoculum and dye removal rate and a negative relation between initial dye concentration and final dye removal percentages were proved. Nevertheless, negative effects where only observed in concentrations much higher than those expected in real effluents.

Also, higher specific decolorization rates and complete removal of dye mixture

in a range of temperatures and agitation conditions are interesting features for a future biotechnological application of Trichosporon akiyoshidainum HP 2023 in colored effluent treatment. 
Acknowledgements: This work was supported by Agencia Nacional de Promoción

Científica y Tecnológica-FONCYT, Consejo Nacional de Investigaciones Científicas y

Técnicas CONICET, and Consejo de Investigaciones de la Universidad Nacional de Tucumán, CIUNT.

Conflict of interest: We state that there are no conflicts of interests in this study

Compliance with ethical standards: This article does not contain any studies with human participants or animals performed by any of the authors.

\section{REFERENCES}

[1] Sen SK, Raut S, Bandyopadhyay P, Raut S. Fungal decolouration and degradation of azo dyes: a review. Fungal Biol Rev. 2016;30(3):112-133.

[2] Nikam M, Patil S, Patil U, Khandare R, Govindwar S, Chaudhari A. Biodegradation and detoxification of azo solvent dye by ethylene glycol tolerant ligninolytic ascomycete strain of Pseudocochliobolus verruculosus NFCCI 3818. Biocatal Agric Biotechnol. 2017;9:209-217.

[3] Das N, Charumathi D. Remediation of synthetic dyes from wastewater using yeast An overview. Indian J Biotechnol. 2012;11:369-380.

[3] Das N, Charumathi D. Remediation of synthetic dyes from wastewater using yeast An overview. Indian J Biotechnol. 2012;11:369-380.

[4] Dias AA, Lucas MS, Sampaio A, Peres JA, Becerra RF. Decolorization of azo dyes by yeasts. The Handbook of Environmental Chemistry, vol. 9: Biodegradation of azo dyes, Springer-Verlag, Berlin. 2010.

[5] Pajot HF, Figueroa LIC, Spencer JF, Fariña JI. Phenotypical and genetic characterization of Trichosporon sp. HP-2023. A yeast isolate from Las Yungas 
rainforest (Tucumán, Argentina) with dye-decolorizing ability. Antonie Van Leeuwenhoek. 2008;94(2):233-244.

[6] Mahmoud MS. Decolorization of certain reactive dye from aqueous solution using Baker's Yeast (Saccharomyces cerevisiae) strain. HBRC Journal. 2016;12(1):88-98. [7] Singh RL, Singh PK, Singh RP. Enzymatic decolorization and degradation of azo dyes-A review. Int Biodeter Biodegrad. 2015;104,21-31.

[8] Kahn R, Bhawana P, Fulekar MH. Microbial decolorization and degradation of synthetic dyes: a review. Rev Environ Sci Biotechnol. 2012;12(1):75-97.

[9] Pajot HF, Figueroa LIC, Fariña JI. Dye-decolorizing activity in isolated yeasts from the ecoregion of Las Yungas (Tucuman, Argentina). Enzyme Microb Technol. 2007;40:1503-1511.

[10] Ramalho PA, Cardoso MH, Cavaco-Paulo A, Ramalho MT. Characterization of azo reduction activity in a novel ascomycete yeast strain. Appl Environ Microbiol. 2004;70:2279-2288.

[11] O’Neill C, Hawkes FR, Hawkes DL, Laurenco ND, Pinheiro HM, Delée W. Review: Color in textile effluents - sources, measurement, discharge consents and simulation: a review. J Chem Technol Biotechnol. 1999;74:1009-1018.

[12] Heinzkill M, Bech L, Halkier T, Schneider P, Anke T. Characterization of laccases and peroxidases from wood-rotting fungi (family Coprinaceae). Appl Environ Microbiol. 1998;64:1601-1606.

[13] Castillo MD, Stenstrom J, Ander P. Determination of manganese peroxidase activity with 3-methyl-2-benzothiazolinone hydrazone and 3-(dimethylamino) benzoic acid. Anal Biochem. 1994;218:399-404. 
[14] Rodríguez-López JN, Escribano J, García-Cánovas F. A continuous spectrophotometric method for the determination of monophenolase activity of tyrosinase using 3 methyl-2-benzothiazolinone hydrazone. Anal Biochem. 1994;216(1):205-12.

[15] Pajot HF, Delgado OD, Figueroa LIC, Fariña JI. Unraveling the decolourizing ability of yeast isolates from dye-polluted and virgin environments: an ecological and taxonomical overview. Antonie Van Leeuwenhoek. 2011;99(3):443-456.

[16] Mohan V, Madhumitha M, Menon S, Saranya K. Isolation and Sereening of potential Dye decolorizing bacteria from Textile dye effluents in Tamil Nadu. J Acad Ind Res. 2013;4(2): 74-79.

[17] Tan L, Ning S, Zhang X, Shi S. Aerobic decolorization and degradation of azo dyes by growing cells of a newly isolated yeast Candida tropicalis TL-F1. Bioresour Technol. 2013;138:307-313.

[18] Ma L, Zhuo R, Liu H, Yu D, Jiang M, Zhang X, Yang Y. Efficient decolorization and detoxification of the sulfonated azo dye Reactive Orange 16 and simulated textile wastewater containing Reactive Orange 16 by the white-rot fungus Ganoderma sp. En3 isolated from the forest of Tzu-chin Mountain in China. Biochem Eng J. 2014;82:1-9. [19] Marim R, Oliveira A, Marquezoni R, Servantes J, Cardoso B, Linde G, Colauto N, Valle J. Use of sugarcane molasses by Pycnoporus sanguineus for the production of laccase for dye decolorization. Gen Mol Res. 2016;15.

[20] Dedyukhina EG, Eroshin VK. Essential metal ions in the control of microbial metabolism. Process Biochem. 1991;26(1):31-37. 
[21] Martorell MM, Pajot HF, Rovati JI, Figueroa LIC. Optimization of culture medium composition for Mn-peroxidase and tyrosinase production during Reactive Black 5 decolourization by yeast Trichosporon akiyoshidainum. Yeast. 2012;29:137-144. [22] Koyani, RD, Sanghvi GV, Sharma RK, Rajput KS. Contribution of lignin degrading enzymes in decolourisation and degradation of reactive textile dyes. Int Biodet Biodeg, (2013)77:1-9.

[23] Gomathi V, Saravanakumar K, Kathiresan K. Bio removal of malachite green by mangrove-derived Aplanochytrium sp., KGA2512. Afr J Microbiol Res. 2013;7(24): 3056-3065.

[24] Jasińska A, Paraszkiewicz K, Sip A, Długoński J. Malachite green decolorization by the filamentous fungus Myrothecium roridum - Mechanistic study and process optimization. Bioresour Technol. 2015;194:43-48.

[25] Afreen S, Bano F, Ahmad N, Fatma T. Screening and optimization of laccase from cyanobacteria with its potential in decolorization of anthraquinonic dye Remazol Brilliant Blue R. Biocatal Agric Biotechnol. 2017;10:403-410.

[26] Zhuo R, Yuan P, Yang Y, Zhang S, Ma F, Zhang X. Induction of laccase by metal ions and aromatic compounds in Pleurotus ostreatus HAUCC 162 and decolorization of different synthetic dyes by the extracellular laccase. Biochem Eng J. 2017;117, Part B:62-72.

[27] Martorell MM, Pajot HF, Ahmed PM, de Figueroa LI. Biodecoloration of Reactive Black 5 by the methylotrophic yeast Candida boidinii MM 4035. J Environ Sci. 2017;53: 78-87. 
[28] Ekramul Karim M, Dhar K, Towhid Hossain M. Co-metabolic decolorization of a textile reactive dye by Aspergillus fumigatus. Int J Environ Sci Technol. 2017;14(1):177-186.

[29] Imran M, Arshad M, Negm F, Khalid A, Shaharoona B, Hussain S, Crowley DE. Yeast extract promotes decolorization of azo dyes by stimulating azoreductase activity in Shewanella sp. strain IFN4. Ecotoxicol Environ Saf. 2016;124:42-49.

[30] Balapure KH, Jain K, Chattaraj S, Bhatt NS, Madamwar D. Co-metabolic degradation of diazo dye-Reactive blue 160 by enriched mixed cultures BDN. J Hazard Mater. 2014;279:85-95.

[31] Gupta VK, Kumar R, Nayak A, Saleh TA, Barakat MA. Adsorptive removal of dyes from aqueous solution onto carbon nanotubes: a review. Adv Colloid Interface Sci $2013 ; 193: 24-34$

[32] Ali NF, El-Mohamedy RSR. Microbial decolourization of textile waste water. J Saudi Chem Soc. 2012;16:117-123.

[33] Tan L, He M, Song L, Fu X, Shi S. Aerobic decolorization, degradation and detoxification of azo dyes by a newly isolated salt-tolerant yeast Scheffersomyces spartinae TLHS-SF1. Bioresour Technol. 2016;203:287-294.

[34] Song L, Shao Y, Ning S, Tan L. Performance of a newly isolated salt-tolerant yeast strain Pichia occidentalis G1 for degrading and detoxifying azo dyes. Bioresour Technol, 2017;233:21-29.

[35] Martorell MM. Participación de mecanismos enzimáticos en biodecoloración con levaduras aisladas de ambientes naturales. Aspectos básicos y aplicación biotecnológica. Tucumán (Argentina).Universidad Nacional de Tucumán. 2015. 
[36] Pajot HF, Martorell MM, de Figueroa LIC. Ecology of Dye Decolorizing Yeasts.

Bioremediation in Latin America. Springer International Publishing. 2014. 
Table 1. Results from the first fractional factorial design for Reactive Black 5 removal optimization with T. akiyoshidainum $\mathrm{HP}_{2023}$. Units: biomass g $\mathrm{L}^{-}$ ${ }^{1}$, dye removal $\%, \nu, \mathrm{mg} \mathrm{g}^{-1} \mathrm{~h}^{-1}$.

\begin{tabular}{|c|c|c|c|c|c|c|c|c|c|c|c|c|c|c|}
\hline 1 & 1 & 0,0565 & 0,125 & 0,25 & 0,075 & 97,17 & 99,48 & 2,40 & 4,19 & 5,87 & 4,52 & 6,19 & 6,06 & \\
\hline 2 & 3 & 0,0565 & 0,125 & 0,25 & 0,025 & 93,67 & 98,47 & 2,42 & 5,19 & 6,20 & 4,45 & 4,40 & 6,33 & 1,55 \\
\hline 3 & 1 & 0,1695 & 0,125 & 0,25 & 0,025 & 88,65 & 88,22 & 2,79 & 4,12 & 6,80 & ,50 & & 5,02 & 1,69 \\
\hline 4 & 3 & 0,1695 & 0,125 & 0,25 & 0,075 & 97,10 & 100,00 & 2,62 & 6,80 & 6,38 & & 50 & 6,31 & 1,25 \\
\hline 5 & 1 & 0,0565 & 0,375 & 0,25 & 0,025 & 98,56 & 100,00 & 2,45 & 4,67 & 631 & & 6,72 & 6,77 & 1,80 \\
\hline 6 & 3 & 0,0565 & 0,375 & 0,25 & 0,075 & 86,74 & 99,78 & 2,85 & 5,30 & & & 4,83 & 4,98 & 1,54 \\
\hline 7 & 1 & 0,1695 & 0,375 & 0,25 & 0,075 & 93,79 & 97,87 & 3,18 & 4,71 & & 55 & 8,50 & 4,69 & 1,65 \\
\hline 8 & 3 & 0,1695 & 0,375 & 0,25 & 0,025 & 96,63 & 99,86 & 2,93 & & & 5,74 & 5,34 & 5,08 & 1,31 \\
\hline 9 & 1 & 0,0565 & 0,125 & 0,75 & 0,025 & 89,15 & 99,32 & 2,14 & & 5,40 & 4,46 & 4,78 & 6,78 & 2,13 \\
\hline 10 & 3 & 0,0565 & 0,125 & 0,75 & 0,075 & 88,27 & 100,00 & 2,75 & 4,1 & 5,25 & 4,29 & 3,98 & 5,20 & 1,96 \\
\hline 11 & 1 & 0,1695 & 0,125 & 0,75 & 0,075 & 90,42 & 92,62 & & 3,69 & 5,38 & 5,27 & 7,01 & 5,79 & 2,03 \\
\hline 12 & 3 & 0,1695 & 0,125 & 0,75 & 0,025 & 82,40 & 8320 & & 7,06 & 5,45 & 5,26 & 6,14 & 4,60 & 0,92 \\
\hline 13 & 1 & 0,0565 & 0,375 & 0,75 & 0,075 & 74,06 & 97,30 & & 4,40 & 5,52 & 5,17 & 5,51 & 4,78 & 1,80 \\
\hline 14 & 3 & 0,0565 & 0,375 & 0,75 & 0,025 & 75,66 & & 2,63 & 5,13 & 5,53 & 5,27 & 4,66 & 4,57 & 1,53 \\
\hline 15 & 1 & 0,1695 & 0,375 & 0,75 & 0,025 & 97.97 & 0,00 & 2,41 & 3,22 & 5,71 & 5,72 & 6,94 & 6,95 & 2,65 \\
\hline 16 & 3 & 0,1695 & 0,375 & 0,75 & 0,075 & & & 2,99 & 5,15 & 5,66 & 5,56 & 4,96 & 4,74 & 1,56 \\
\hline 17 & 1 & 0,0565 & 0,125 & 0,25 & 0,075 & & & 2,52 & 4,18 & 5,88 & 4,64 & 6,00 & 6,07 & 1,88 \\
\hline 18 & 3 & 0,0565 & 0,125 & 0,25 & 0,02 & & 100,00 & 2,54 & 5,18 & 6,21 & 4,71 & 4,17 & 6,28 & 1,62 \\
\hline 19 & 1 & 0,1695 & 0,125 & 0,25 & & 1 & 98,79 & 2,91 & 4,11 & 6,81 & 5,60 & 8,08 & 5,58 & 1,98 \\
\hline 20 & 3 & 0,1695 & 0,125 & 0,25 & & 99,38 & 99,64 & 2,74 & 6,79 & 6,39 & 5,45 & 6,87 & 5,88 & 1,19 \\
\hline 21 & 1 & 0,0565 & 0,375 & & & 100,00 & 100,00 & 2,57 & 4,66 & 6,32 & 5,45 & 6,86 & 6,55 & 1,81 \\
\hline 22 & 3 & 0,0565 & 0,375 & & & 99,54 & 100,00 & 2,97 & 5,29 & 6,07 & 5,16 & 4,54 & 5,45 & 1,54 \\
\hline 23 & 1 & 0,1695 & 0,375 & & & 98,68 & 98,53 & 3,30 & 4,70 & 6,62 & 5,70 & 8,86 & 4,85 & 1,70 \\
\hline 24 & 3 & 0,1695 & 0,375 & 0,25 & 0,025 & 97,87 & 100,00 & 3,05 & 5,86 & 6,63 & 5,75 & 6,03 & 5,33 & 1,42 \\
\hline 25 & 1 & 0,0565 & 0,125 & & 0,025 & 73,12 & 92,31 & 2,26 & 3,79 & 5,41 & 4,27 & 4,63 & 5,10 & 1,92 \\
\hline
\end{tabular}




\begin{tabular}{|c|c|c|c|c|c|c|c|c|c|c|c|c|c|c|}
\hline 26 & 3 & 0,0565 & 0,125 & 0,75 & 0,075 & 91,08 & 100,00 & 2,87 & 4,11 & 5,26 & 4,33 & 3,89 & 5,10 & 905 \\
\hline 27 & 1 & 0,1695 & 0,125 & 0,75 & 0,075 & 88,24 & 92,40 & 2,65 & 3,68 & 5,39 & 4,92 & 7,03 & 5,21 & \\
\hline 28 & 3 & 0,1695 & 0,125 & 0,75 & 0,025 & 67,30 & 70,35 & 2,90 & 7,05 & 5,46 & 5,54 & 6,28 & & \\
\hline 29 & 1 & 0,0565 & 0,375 & 0,75 & 0,075 & 99,73 & 100,00 & 2,64 & 4,39 & 5,53 & 4,98 & 02 & & \\
\hline 30 & 3 & 0,0565 & 0,375 & 0,75 & 0,025 & 96,35 & 100,00 & 2,75 & 5,12 & 5,54 & 01 & 4,44 & 5,95 & 1,66 \\
\hline 31 & 1 & 0,1695 & 0,375 & 0,75 & 0,025 & 96,88 & 100,00 & 2,53 & 3,21 & 5,72 & & & ה & 2,40 \\
\hline 32 & 3 & 0,1695 & 0,375 & 0,75 & 0,075 & 91,00 & 100,00 & 3,11 & 5,14 & & & & 4,48 & 1,49 \\
\hline 33 & 2 & 0,113 & 0,25 & 0,5 & 0,05 & 99,68 & 100,00 & 2,91 & 5,21 & & &, 36 & 5,50 & 1,54 \\
\hline 34 & 2 & 0,113 & 0,25 & 0,5 & 0,05 & 94,63 & 99,21 & 2,94 & 5,20 & & & 5,40 & 6,05 & 1,79 \\
\hline
\end{tabular}


Table 2. Results from the second fractional factorial design for Reactive Black 5 optimization with T. akiyoshidainum HP2023. Units: biomass g L ${ }^{-1}$, dye removal \%, $v, \mathrm{mg} \mathrm{g}^{-1} \mathrm{~h}^{-1}$.

\begin{tabular}{|c|c|c|c|c|c|c|c|c|c|c|c|c|c|c|}
\hline 1 & 0,5 & 0,025 & 0,06 & 0,25 & 0,1 & 79,40 & 79,48 & 1,76 & 1,70 & 5,87 & 3,89 &, 03 & 7,20 & 3,73 \\
\hline 2 & 1 & 0,025 & 0,06 & 0,1 & 0,06 & 83,07 & 93,77 & 2,18 & 3,20 & 6,20 & & & & 2,34 \\
\hline 3 & 0,5 & 0,05 & 0,06 & 0,1 & 0,1 & 80,10 & 79,51 & 1,38 & 1,50 & 6,80 & & & 9,27 & 4,23 \\
\hline 4 & 1 & 0,05 & 0,06 & 0,25 & 0,06 & 77,88 & 80,97 & 2,14 & 3,00 & & & 65 & 5,81 & 2,15 \\
\hline 5 & 0,5 & 0,025 & 0,1 & 0,25 & 0,06 & 94,79 & 94,82 & 1,30 & 1,60 & & & 6,63 & 11,64 & 4,73 \\
\hline 6 & 1 & 0,025 & 0,1 & 0,1 & 0,1 & 99,11 & 100,00 & 2,50 & 3,20 & & 29 & 4,00 & 6,33 & 2,50 \\
\hline 7 & 0,5 & 0,05 & 0,1 & 0,1 & 0,06 & 94,93 & 93,03 & 1,90 & 2,00 & 6,61 & 6,68 & 7,85 & 7,98 & 3,71 \\
\hline 8 & 1 & 0,05 & 0,1 & 0,25 & 0,1 & 97,25 & 100,00 & & 3,60 & 6,62 & 4,52 & 6,67 & 6,47 & 2,22 \\
\hline 9 & 0,5 & 0,025 & 0,06 & 0,25 & 0,1 & 78,35 & 78,03 & 1,40 & 1,80 & 5,40 & 4,07 & 6,04 & 8,94 & 3,46 \\
\hline 10 & 1 & 0,025 & 0,06 & 0,1 & 0,06 & 88,90 & & 2,20 & 2,60 & 5,25 & 3,90 & 3,98 & 6,45 & 2,82 \\
\hline 11 & 0,5 & 0,05 & 0,06 & 0,1 & 0,1 & 79,45 & & 1,20 & 2,10 & 5,38 & 5,31 & 7,16 & 10,57 & 2,94 \\
\hline 12 & 1 & 0,05 & 0,06 & 0,25 & 0,06 & 77,60 & & 2,00 & 2,90 & 5,45 & 4,94 & 6,47 & 6,20 & 2,22 \\
\hline 13 & 0,5 & 0,025 & 0,1 & 0,25 & 0,06 & & & 0,80 & 1,90 & 5,52 & 5,29 & 6,64 & 18,04 & 3,77 \\
\hline 14 & 1 & 0,025 & 0,1 & 0,1 & 0,1 & & 100,00 & 2,30 & 3,30 & 5,53 & 4,26 & 3,95 & 6,79 & 2,42 \\
\hline 15 & 0,5 & 0,05 & 0,1 & 0,1 & 006 & & 94,44 & 1,10 & 1,60 & 5,71 & 6,95 & 7,71 & 13,83 & 4,71 \\
\hline 16 & 1 & 0,05 & 0,1 & 0,25 & & & 100,00 & 2,10 & 3,00 & 5,66 & 4,31 & 6,69 & 7,48 & 2,66 \\
\hline 17 & 0,75 & 0,0375 & 0,08 & 0,175 & & & 90,67 & 2,90 & 2,60 & 5,88 & 6,64 & 6,55 & 4,88 & 2,78 \\
\hline 18 & 0,75 & 0,0375 & 0,08 & 0,1 & & 62 & 91,03 & 2,30 & 2,90 & 5,86 & 4,23 & 6,69 & 6,22 & 2,51 \\
\hline
\end{tabular}


Table 3. Results from the full factorial design for Reactive Black 5 removal optimization with T. akiyoshidainum HP2023. Units: biomass $g$ L ${ }^{-1}$, dye removal $\%, v, \mathrm{mg} \mathrm{g}^{-1} \mathrm{~h}^{-1}$.

\begin{tabular}{llllllllllll}
$\mathbf{1}$ & 0 & 0 & 74,40 & 93,95 & 2,64 & 3,06 & 6,61 & 5,30 & 3,95 & 4,70 & 1,45 \\
$\mathbf{2}$ & 0,125 & 0 & 78,94 & 88,16 & 2,68 & 3,54 & 5,60 & 4,32 & 3,73 & 4,91 & 1,32 \\
$\mathbf{3}$ & 0 & 0,05 & 74,90 & 81,75 & 3,06 & 5,22 & 6,04 & 7,12 & 6,38 & 4,08 & 0,95 \\
$\mathbf{4}$ & 0,125 & 0,05 & 95,44 & 100,17 & 3,64 & 6,10 & 5,61 & 4,60 & 5,38 & 4,37 & 0,68 \\
$\mathbf{5}$ & 0 & 0 & 77,12 & 95,28 & 2,64 & 3,24 & 6,61 & 4,50 & 3,90 & 4,87 & 1,35 \\
$\mathbf{6}$ & 0,125 & 0 & 81,37 & 100,00 & 2,72 & 3,68 & 5,60 & 4,21 & 3,75 & 4,99 & 1,13 \\
$\mathbf{7}$ & 0 & 0,05 & 74,64 & 82,60 & 3,08 & 5,42 & 6,04 & 7,68 & 6,76 & 4,04 & 0,90 \\
$\mathbf{8}$ & 0,125 & 0,05 & 90,58 & 100,00 & 3,44 & 7,10 & 5,61 & 4,95 & 4,64 & 4,39 & 0,59 \\
\hline
\end{tabular}




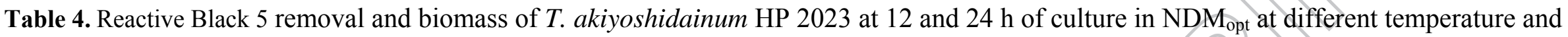
agitation conditions.

\begin{tabular}{|c|c|c|c|c|}
\hline & $12 \mathrm{~h}$ & $24 \mathrm{~h}$ & $12 \mathrm{~h}$ & $24 \mathrm{~h}$ \\
\hline $20^{\circ} \mathrm{C}$ & $4,10 \pm 0,48$ & $6,44 \pm 0,45$ & $83,40 \pm 0,55$ & $93,23 \pm 0,75$ \\
\hline $25^{\circ} \mathrm{C}$ & $3,56 \pm 0,14$ & $6,6 \pm 0,7$ & $93,00 \pm 3,43$ & $99,89 \pm 0,11$ \\
\hline $30^{\circ} \mathrm{C}$ & $1,57 \pm 0,01$ & $1,93 \pm 0,24$ & $53,32 \pm 0,55$ & $56,90 \pm 0,66$ \\
\hline 200 rpm & $3,38 \pm 0,16$ & $5,18 \pm 0,11$ & $80,90 \pm 0,98$ & $96,16 \pm 3,27$ \\
\hline $250 \mathrm{rpm}$ & $3,83 \pm 0,04$ & $5,88 \pm 0,07$ & $86,84 \pm 0,76$ & $100,0 \pm 0,01$ \\
\hline $300 \mathrm{rpm}$ & $3,86 \pm 0,14$ & $5,48 \pm 0,11$ & $76,26 \pm 1,00$ & $91,12 \pm 0,19$ \\
\hline
\end{tabular}


Table 5. Biomass $\left(\mathrm{g} \mathrm{L}^{-1}\right)$, dye removal (\%), $v\left(\mathrm{mg} \mathrm{g}^{-1} \mathrm{~h}^{-1}\right)$ and $\mathrm{pH}$ values and biomass color at 12 and $24 \mathrm{~h}$ of culture of T. akiyoshidainum HP 2023 in media $\mathrm{NDM}_{\mathrm{opt}}$ and NDM with each dye and the mixture of them. RB5, Reactive Black 5, RY84 : Reactive Yellow 84, RR121, Reactive Red 121 RB221: Reactive Blue 221

\begin{tabular}{|c|c|c|c|c|c|c|c|c|c|c|}
\hline \multirow[t]{2}{*}{ RB5 } & NDM & 81.47 & 97.67 & 4,06 & 6,10 & 3,12 & 1,24 & 2,63 & 2,38 & Beige \\
\hline & $\mathrm{NDM}_{\text {opt. }}$ & 85.37 & 98.25 & 2,53 & 4,90 & & 1,54 & 5,89 & 6,18 & Beige \\
\hline \multirow[t]{2}{*}{ RY84 } & NDM & 96.03 & 96.74 & 3,80 & 5,36 & 4,35 & 1,54 & 2,83 & 2,41 & Cream \\
\hline & $\mathrm{NDM}_{\text {opt. }}$ & 95.01 & 96.32 & 3,00 & 5,47 & 51 & 1,50 & 5,08 & 5,98 & Cream \\
\hline \multirow[t]{2}{*}{ RR121 } & NDM & 99.43 & 100 & 4,30 & 736 & 3,87 & 1,13 & 2,81 & 2,41 & Red/pink \\
\hline & $\mathrm{NDM}_{\text {opt. }}$ & 97.91 & 98.84 & 2,93 & 5,67 & 5,61 & 1,45 & 5,98 & 6,49 & Red/pink \\
\hline \multirow[t]{2}{*}{ RB221 } & NDM & 100 & 100 & 4,43 & 8,56 & 3,57 & 0,93 & 2,95 & 2,45 & Cream \\
\hline & $\mathrm{NDM}_{\text {opt. }}$ & 100 & 100 & & 5,70 & 5,07 & 1,39 & 4,80 & 6,17 & Cream \\
\hline \multirow[t]{2}{*}{ Mixture } & NDM & 77,94 & 89,73 & 4,86 & 6,73 & 2,67 & 1,11 & 2,75 & 2,42 & Red/pink \\
\hline & $\mathrm{NDM}_{\text {opt. }}$ & 82,45 & 89,80 & 3,20 & 5,71 & 4,27 & 1,31 & 5,18 & 5,86 & Red/pink \\
\hline
\end{tabular}


Table 6. Laccase, MnP and Phenoloxidase activities measured in original NDM and in optimized $\left(\mathrm{NDM}_{\mathrm{opt}}\right)$ media after 12 and $24 \mathrm{~h}$ of incubation.

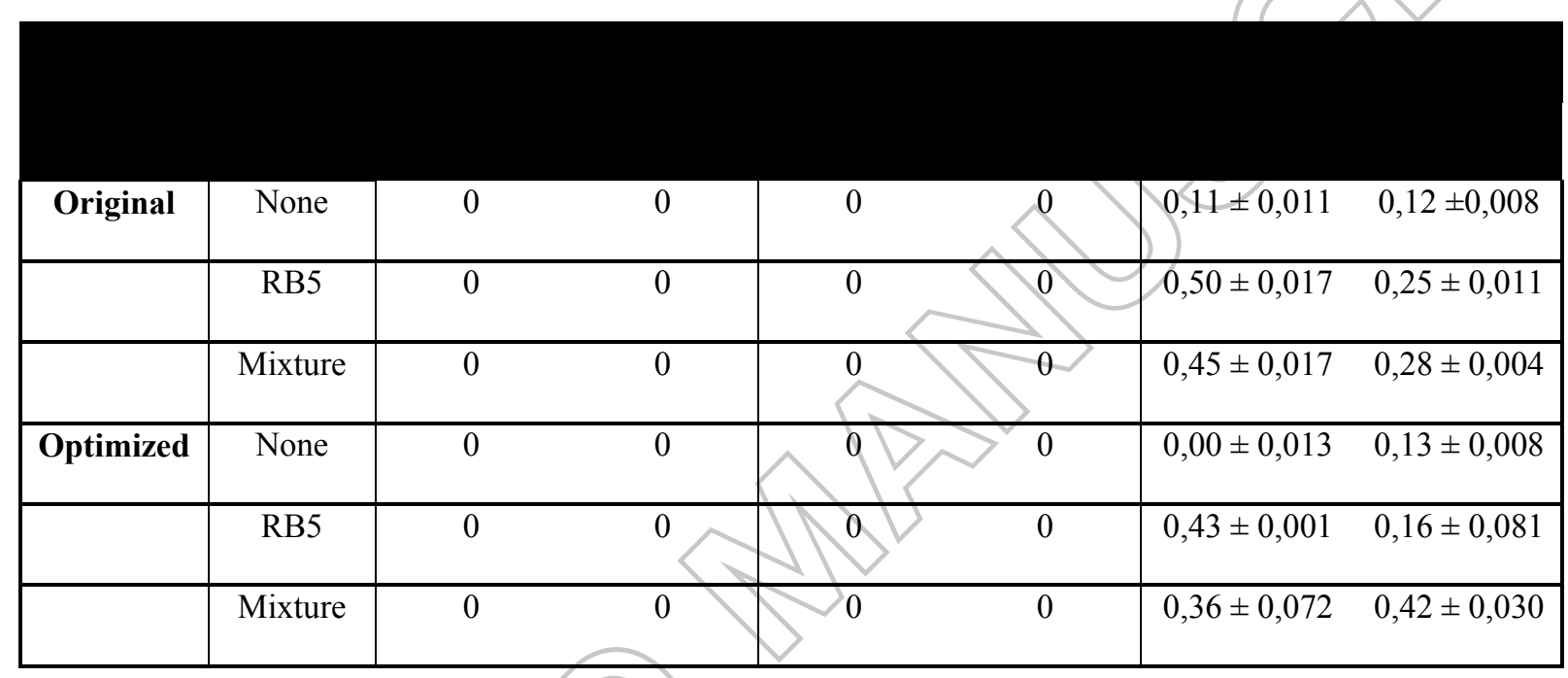




\section{Figure Captions:}

Fig. 1. Chemical structure of dyes (A) Reactive Red 141, (B) Reactive Yellow 84, Reactive Black 5 and (D) Reactive Blue 221

Fig. 2. Reactive Black 5 removal (A) and biomass (B) of T. akiyoshidainum HP 2023 at 12 (white) and $24 \mathrm{~h}$ (black) of culture in different media. M1 glucose/( $\left.\mathrm{NH}_{4}\right)_{2} \mathrm{SO}_{4}, \mathrm{M} 2$ glucose $/ \mathrm{NH}_{4} \mathrm{NO}_{3}, \mathrm{M} 3$ glucose/urea, $\mathrm{M} 4$ glycerol/ $\left(\mathrm{NH}_{4}\right)_{2} \mathrm{SO}_{4}, \mathrm{M} 5$ glycerol $/ \mathrm{NH}_{4} \mathrm{NO}_{3}, \mathrm{M} 6$ glycerol/urea, M7 lactose/( $\left.\mathrm{NH}_{4}\right)_{2} \mathrm{SO}_{4}, \mathrm{M} 8$ lactose $/ \mathrm{NH}_{4} \mathrm{NO}_{3}$, M9 lactose/urea, M10 sucrose/( $\left(\mathrm{NH}_{4}\right)_{2} \mathrm{SO}_{4}, \mathrm{M} 11$ sucrose $/ \mathrm{NH}_{4} \mathrm{NO}_{3}, \mathrm{M} 12$ sucrose/urea

Fig. 3. Dye removal (A) and biomass (B) of T. akiyoshidainum HP 2023 with Reactive Black 5 at 12 and $24 \mathrm{~h}$ of culture in different media. $\mathrm{M1}$ : with both $\mathrm{CaCl}_{2}$ and $\mathrm{MgSO}_{4}$, M2: without both $\mathrm{CaCl}_{2}$ and $\mathrm{MgSO}_{4}, \mathrm{M} 3$ : without $\mathrm{CaCl}_{2}$

Fig. 4. Spectra of supernatants of T. akiyoshidainum HP 2023 with dye mixture in $\mathrm{NDM}_{\mathrm{opt}}$ (left) and NDM (right).

Fig. 5. Biomass (A) and dye-mixture removal (B) of T. akiyoshidainum HP 2023 during culture in $\mathrm{NDM}_{\mathrm{opt}}$ with different initial biomass concentrations.

Fig. 6. Biomass (A) and dye mixture removal (B) of T. akiyoshidainum HP 2023 during culture in $\mathrm{NDM}_{\mathrm{opt}}$ with different initial dye-mixture concentrations. 


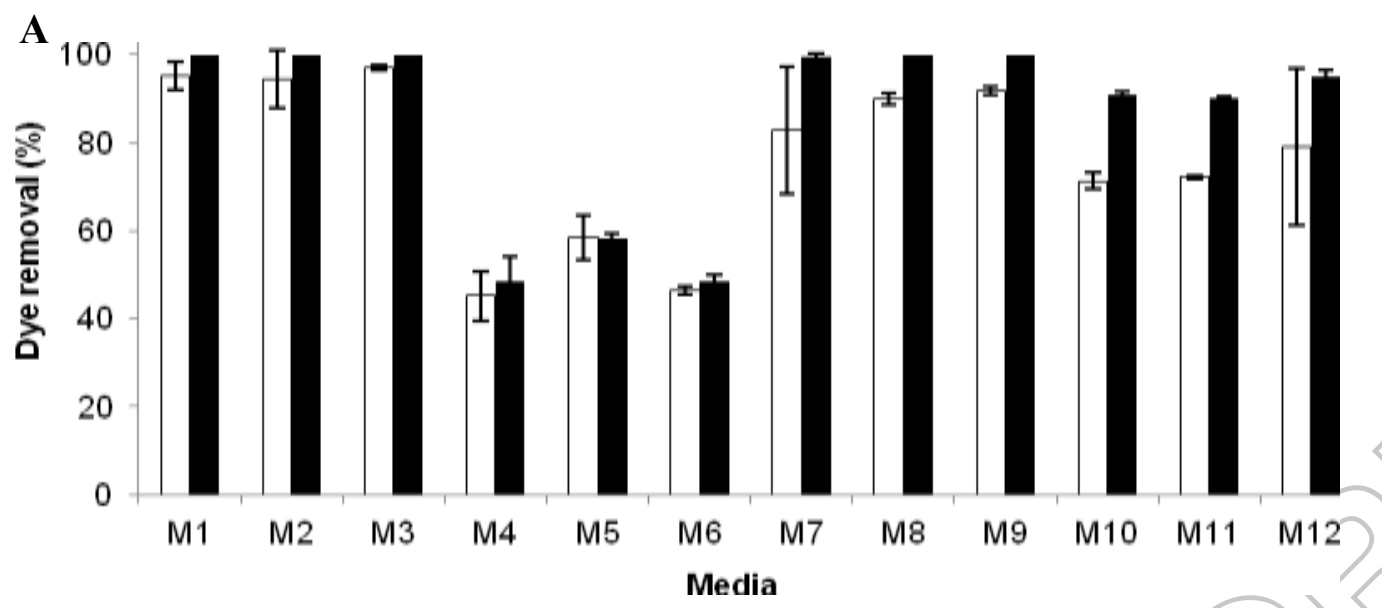

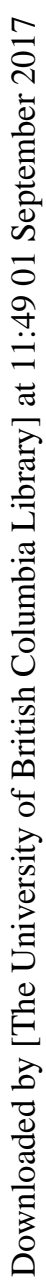

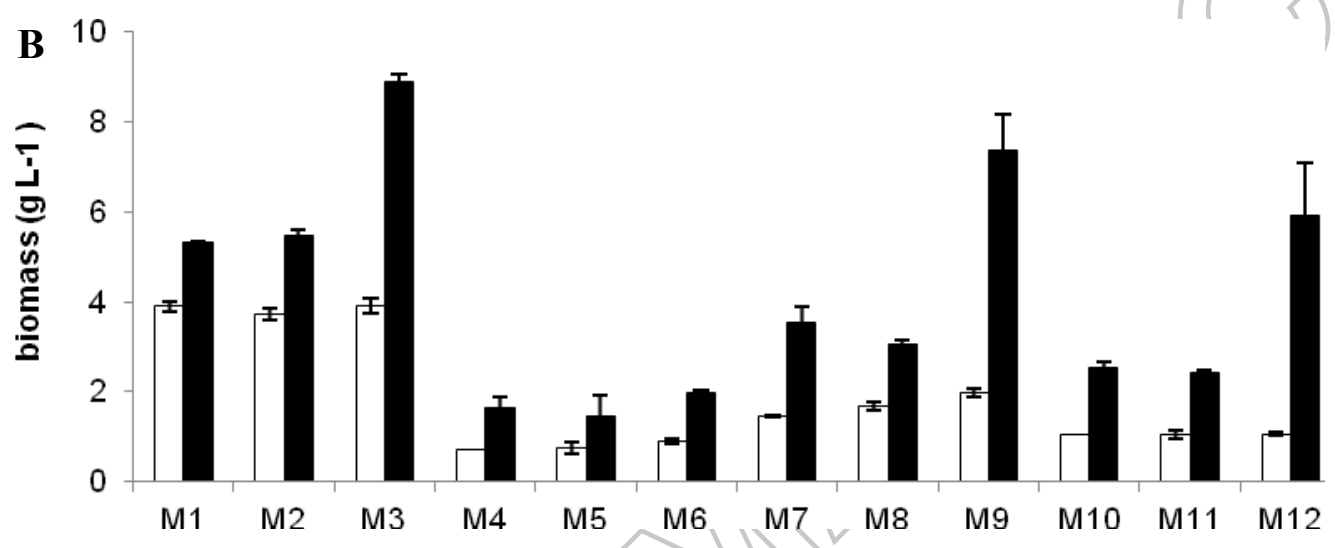

Fig. 2. 

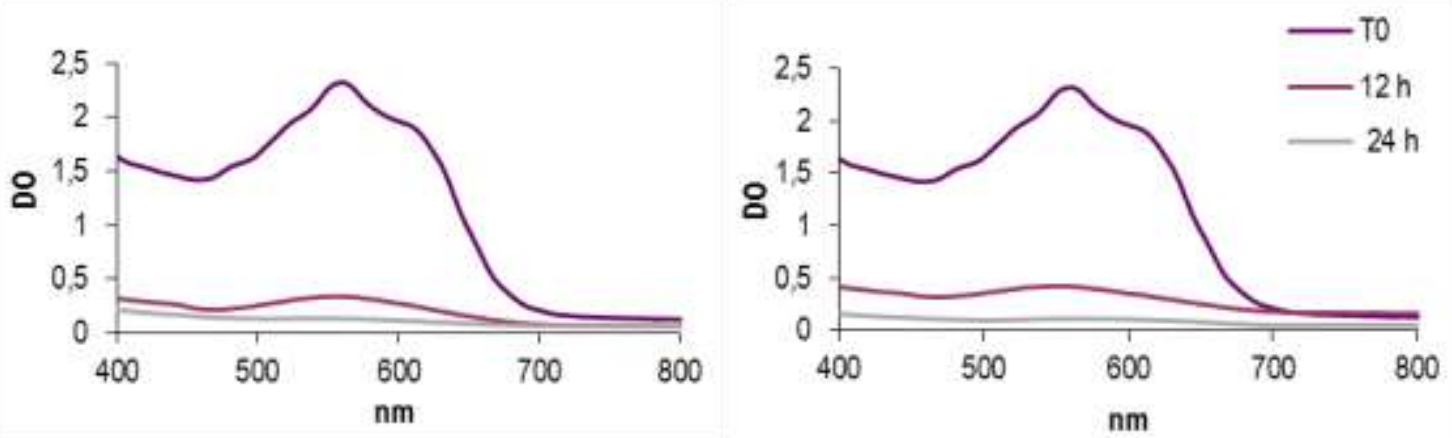

Fig. 4.

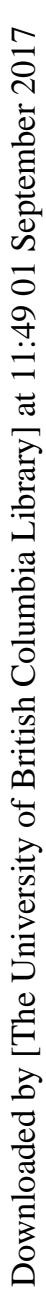



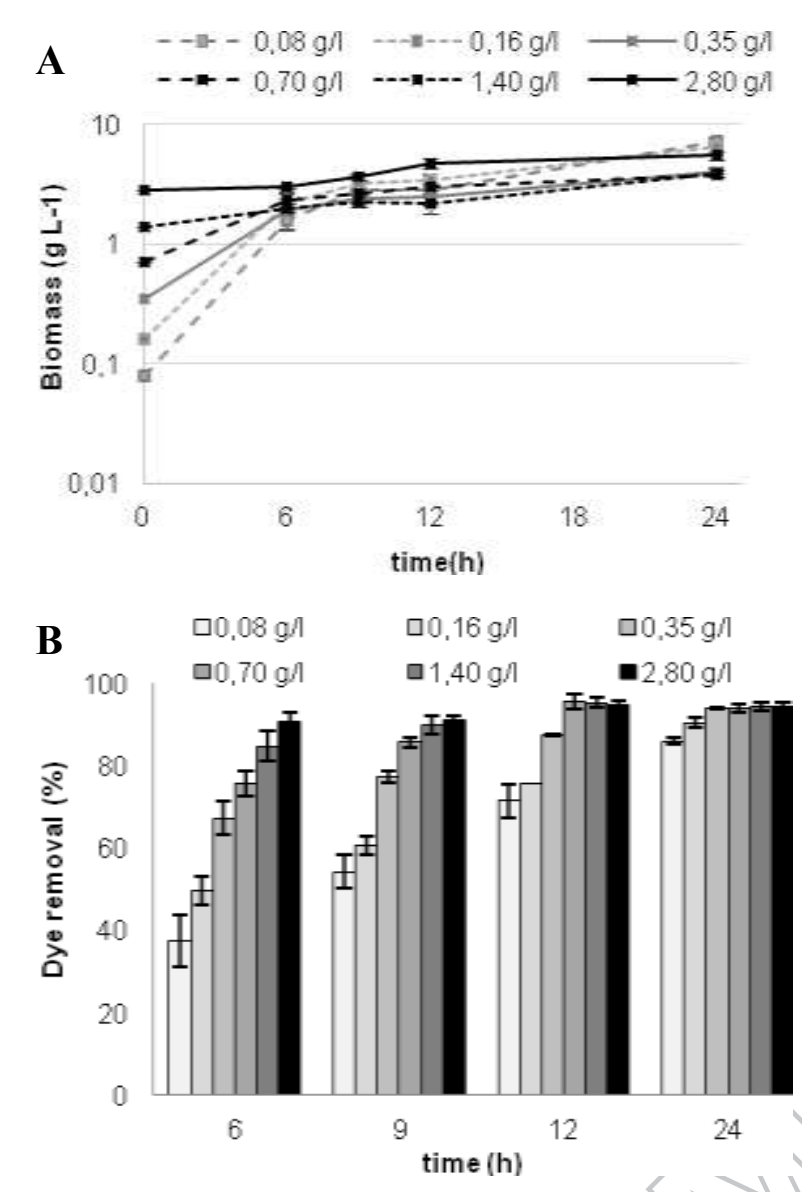

Fig. 5. 

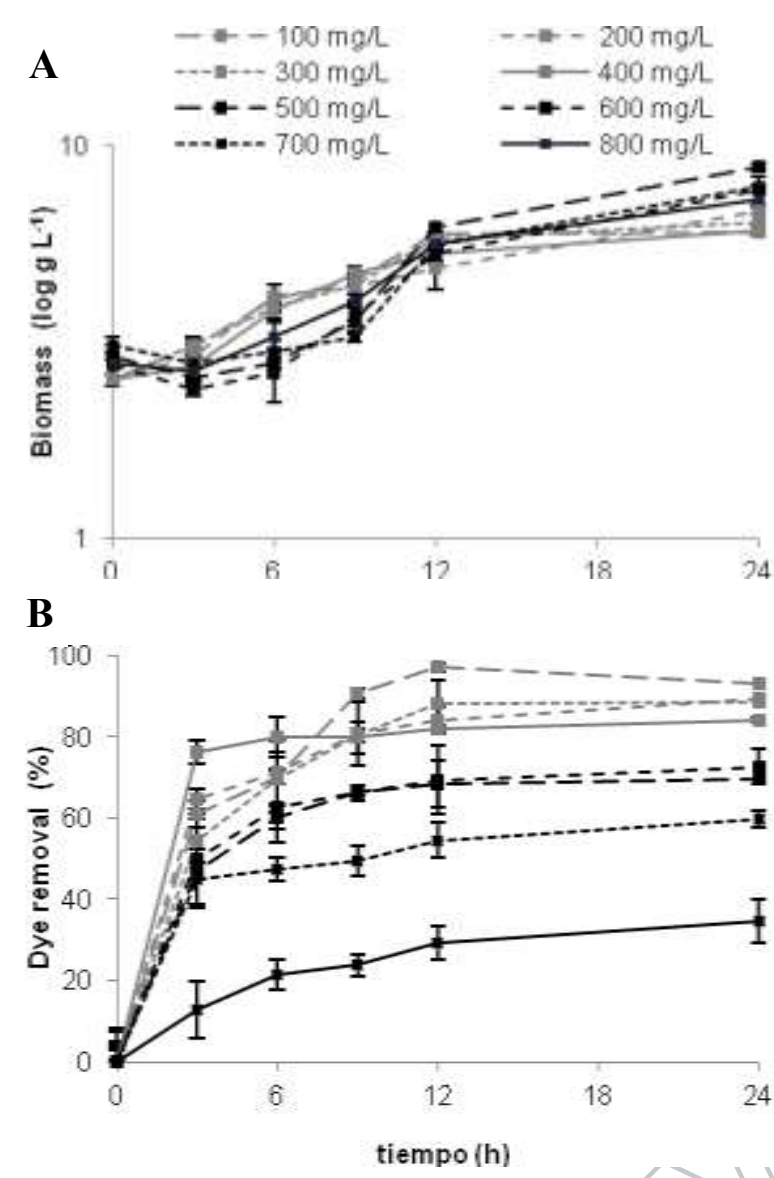

Fig. 6 . 
Table S1. Specific decolorization rates for the media evaluated. M1 glucose/( $\left.\mathrm{NH}_{4}\right)_{2} \mathrm{SO}_{4}$, M2 glucose/ $\mathrm{NH}_{4} \mathrm{NO}_{3}, \mathrm{M} 3$ glucose/urea, M4 glycerol/ $\left(\mathrm{NH}_{4}\right)_{2} \mathrm{SO}_{4}, \mathrm{M} 5$ glycerol $/ \mathrm{NH}_{4} \mathrm{NO}_{3}$, M6 glycerol/urea, M7 lactose/( $\left.\mathrm{NH}_{4}\right)_{2} \mathrm{SO}_{4}, \mathrm{M} 8$ lactose $/ \mathrm{NH}_{4} \mathrm{NO}_{3}$, M9 lactose/urea, M10 sucrose/($\left(\mathrm{NH}_{4}\right)_{2} \mathrm{SO}_{4}, \mathrm{M} 11$ sucrose $/ \mathrm{NH}_{4} \mathrm{NO}_{3}, \mathrm{M} 12$ sucrose/urea

\begin{tabular}{|llllllllllllll|}
\hline & & & & & & & & & & & & & \\
\hline Media & & M1 & M2 & M3 & M4 & M5 & M6 & M7 & M8 & M9 & M10 & M11 & M12 \\
\hline $\begin{array}{l}\text { Time of } \\
\text { culture }\end{array}$ & $\mathbf{1 2} \mathbf{~ h}$ & 3,21 & 4,31 & 4,43 & 10,9 & 2,51 & 9,49 & 9,77 & 9,09 & 8,34 & 11,5 & 11,7 & 13,4 \\
\cline { 2 - 12 } & $\mathbf{2 4} \mathbf{h}$ & 1,60 & 1,56 & 1,00 & 13,3 & 3,36 & 2,27 & 2,40 & 2,79 & 1,21 & 3,05 & 3,15 & 1,43 \\
\hline
\end{tabular}

Table S2. Estimated regression coefficient and corresponding $t$ and $p$ values of dye removal at $12 \mathrm{~h}$. Coef, coefficient for the regression equation. SE Coef, standard error of the Coef. $t$, test statistic with Student's test., $p$ : value associated whit test statistic.

\begin{tabular}{|c|c|c|c|c|c|}
\hline Constant & & 90,47 & 1,717 & 52,7 & 0,000 \\
\hline Lactose & $-0,2$ & $-0,1$ & 1,717 & $-0,06$ & 0,954 \\
\hline Urea & 3,153 & 1,576 & 1,717 & 0,92 & 0,372 \\
\hline Yeast extract & 1,397 & 0,698 & 1,717 & 0,41 & 0,690 \\
\hline $\mathrm{KH}_{2} \mathrm{PO}_{4}$ & $-11,331$ & $-5,666$ & 1,717 & $-3,3$ & 0,005 \\
\hline $\mathrm{MgSO}_{4}$ & $-0,1$ & $-0,05$ & 1,717 & $-0,03$ & 0,977 \\
\hline Lactose $^{*}$ urea & $-4,066$ & $-2,033$ & 1,717 & $-1,18$ & 0,254 \\
\hline Lactose $^{*}$ yeast extract & 0,719 & 0,359 & 1,717 & 0,21 & 0,837 \\
\hline Lactose ${ }^{*} \mathrm{KH}_{2} \mathrm{PO}_{4}$ & 0,514 & 0,257 & 1,717 & 0,15 & 0,883 \\
\hline Lactose $^{*} \mathrm{MgSO}_{4}$ & 4,546 & 2,273 & 1,717 & 1,32 & 0,204 \\
\hline Urea*yeast extract & 4,621 & 2,31 & 1,717 & 1,35 & 0,197 \\
\hline Urea* $\mathrm{KH}_{2} \mathrm{PO}_{4}$ & 2,698 & 1,349 & 1,717 & 0,79 & 0,443 \\
\hline${\text { Urea* }{ }^{*} \mathrm{MSO}_{4}}$ & 2,566 & 1,283 & 1,717 & 0,75 & 0,466 \\
\hline Yeast extract* $\mathrm{KH}_{2} \mathrm{PO}_{4}$ & 0,714 & 0,357 & 1,717 & 0,21 & 0,838 \\
\hline Yeast extract ${ }^{*} \mathrm{MgSO}_{4}$ & $-7,542$ & $-3,771$ & 1,717 & $-2,2$ & 0,043 \\
\hline Central Point & & 1,039 & 5,15 & 0,2 & 0,843 \\
\hline & & $63,87 \%$ & & $R^{2}$ adj & $=29,99 \%$ \\
\hline
\end{tabular}

Table S3. Estimated regression coefficient and corresponding $t$ and $p$ values of dye removal at $12 \mathrm{~h}$. Coef, coefficient for the regression equation. SE Coef, standard error of the Coef. $t$, test statistic with Student's test., $p$ : value associated whit test statistic. 


\begin{tabular}{|c|c|c|c|c|c|}
\hline Constant & & 88,292 & 0,4535 & 194,69 & 0 \\
\hline Lactose & 3,411 & 1,705 & 0,4535 & 3,76 & 0,004 \\
\hline Urea & $-1,37$ & $-0,685$ & 0,4535 & $-1,51$ & 0,165 \\
\hline Yeast extract. & 15,388 & 7,694 & 0,4535 & 16,97 & 0,000 \\
\hline $\mathrm{KH}_{2} \mathrm{PO}_{4}$ & $-3,081$ & $-1,54$ & 0,4535 & $\overline{-3,4}$ & 0,008 \\
\hline $\mathrm{MgSO}_{4}$ & 0,872 & 0,436 & 0,4535 & 0,96 & 0,361 \\
\hline Urea*yeast extract & 2,305 & 1,152 & 0,4535 & 2,54 & 0,032 \\
\hline Urea* $\mathrm{MgSO}_{4}$ & 1,492 & 0,746 & 0,4535 & 1,64 & 0,134 \\
\hline $\mathrm{CtPt}$ & & 0,828 & 1,3605 & 0,61 & 0,558 \\
\hline$S=1,81379$ & & $=97,3$ & & istad & $4,93 \%$ \\
\hline
\end{tabular}

Table S4. Estimated regression coefficient and corresponding $t$ and $p$ values of dye removal at $12 \mathrm{~h}$. Coef, coefficient for the regression equation. SE Coef, standard error of the Coef. $t$, test statistic with Student's test., $p$ : value associated whit test statistic.

\begin{tabular}{|lccccc|}
\hline Constant & & 80,922 & 0,7603 & 106,44 & 0,000 \\
\hline $\mathrm{KH}_{2} \mathrm{PO}_{4}$ & 11,314 & 5,657 & 0,7603 & 7,44 & 0,002 \\
\hline Urea & 5,391 & 2,966 & 0,7603 & 3,9 & 0,018 \\
\hline $\mathrm{KH}_{2} \mathrm{PO}_{4}{ }^{*}$ urea & 6,923 & 3,462 & 0,7603 & 4,55 & 0,010 \\
\hline \multicolumn{1}{|c|}{$\mathbf{S = 2 , 1 5 0 3 8}$} & $\mathbf{R}^{\mathbf{2}}=\mathbf{9 5 , 8 0 \%}$ & $\mathbf{R}^{2}$ ajustado $=\mathbf{9 2 , 6 6 \%}$ \\
\hline
\end{tabular}

